\title{
Microbial Diversity in Soil under Potato Cultivation from Cold Desert Himalaya, India
}

\author{
Priyanka Sati, Kusum Dhakar, and Anita Pandey \\ Biotechnological Applications, G. B. Pant Institute of Himalayan Environment and Development, Kosi-Katarmal, Almora, \\ Uttarakhand 263 643, India \\ Correspondence should be addressed to Anita Pandey; anita@gbpihed.nic.in
}

Received 19 June 2013; Accepted 28 July 2013

Academic Editors: I. Bisht, H. Ford, R. Rico-Martinez, and P. M. Vergara

Copyright (C) 2013 Priyanka Sati et al. This is an open access article distributed under the Creative Commons Attribution License, which permits unrestricted use, distribution, and reproduction in any medium, provided the original work is properly cited.

Mana village (Chamoli district, Uttarakhand, India), situated in high altitudes (3,238 $\mathrm{m}$ above mean sea level) of Indian Himalayan region, represents cold desert climatic conditions. At Mana, potato is grown from May to September, while the site remains snow clad for approximately six months (from October to April). Soil samples, collected from Mana potato fields, were analyzed for cultivable microbial diversity along with the chemical and enzymatic properties. The analysis revealed colonization of soil by microflora in moderate numbers (up to $10^{7} \mathrm{CFU} / \mathrm{g}$ soil) with limited species level. 25 morphologically distinct microbial isolates belonging to Gram +ve and Gram - ve bacteria, actinomycetes, and fungi including yeast were isolated. The bacteria were tentatively identified as species of Bacillus and Pseudomonas, while the majority of the fungal isolates belonged to the species of Penicillium. These microbial isolates possessed plant growth promotion and biocontrol properties assessed mainly in terms of production of indole acetic acid and hydrolytic enzymes and phosphate solubilization. The soil, when used as "inoculum" in plant based bioassays, exhibited positive influence on plant growth related parameters. The limited diversity of cold tolerant microbial species also extends opportunity to understand the resilience possessed by these organisms under low temperature environment.

\section{Introduction}

Microorganisms are ubiquitous in nature; their distribution is governed by environmental specificities. Extreme environmental conditions are not uncommon, and the microbial diversity of such areas is of particular interest because of the superb adaptability of the native microbes. Due to slow growth rate and difficulty of handling, relatively little attention has been given to cold adapted psychrophiles or psychrotolerant microbes. Decrease in microbial population with a concomitant increase in the altitude has been reported [1]. Under low temperature environments, the importance and distinction between psychrophiles and psychrotrophs or psychrotolerants have also been recognized [2]. Psychrotolerant microbes are important in high-altitude agroecosystems since they survive and retain their functionality at low temperature conditions, while growing optimally at warmer temperatures [3].

The Indian Himalayan region (IHR) occupies special place in the mountain ecosystems of the world. The mountain agroecosystems are characterized by difficult terrain, inadequate infrastructure, inaccessibility and marginal societies, lack of irrigation, severe top soil erosion, and overall external inputs to the system. Agricultural production in the mountains is, to a large extent, influenced by low organic matter, soil moisture status, and colder conditions. Therefore, hill agriculture is, by and large, a low input, low production and subsistence but a sustainable system. The cold adapted microbes that possess various plant growth promotion abilities can be utilized for increased plant production especially in the low temperature environments [4-7].

Potato is grown in more than 150 countries in the world, India being at third place among the ten best producers with approximately 7.5 percent of the world's total production (http://agropedia.iitk.ac.in). In India, potato is also grown in mountain states including Uttarakhand. Potato fields in Mana village (Chamoli district, Uttarakhand) where soil remains influenced by snow for approximately six months of the year (October-April) extend unique opportunity to examine the soil microbial communities from diversity, biotechnological applications, and ecological resilience viewpoints. In the 
present study, soil samples collected from the cold desert area under potato cultivation in IHR have been analyzed for the diversity of microorganisms with particular reference to their plant growth promoting abilities along with the chemical and enzymatic analyses.

\section{Materials and Methods}

2.1. Study Location. The soil samples were collected from potato fields at Mana village representing cold desert climatic conditions $\left(30^{\circ} 46^{\prime} 24.8^{\prime \prime} \mathrm{N} ; 79^{\circ} 29^{\prime} 33.4^{\prime \prime} \mathrm{E} ; 3,238 \mathrm{~m}\right.$ above mean sea level). The samples were collected from 3 different terraces; 5 samples from each terrace were mixed for obtaining composite samples. The $\mathrm{pH}$ of soil was 5.9. The site remains snow clad from October to April, maintaining subzero temperature. Mana that lies $3 \mathrm{Km}$ north of Badrinath (Chamoli district, Uttarakhand, India) is recognized as the last Indian village toward the Indo-Tibet border. The village represents a microecosystem consisting of the local community and the livestock along with physical and organic resources. The local community migrates to lower altitudes (Gopeshwar, Chamoli district) during winters every year and returns when the snow thaws (http://myyatradiary.blogspot.in).

2.2. Soil Analysis (Chemical and Enzymatic). The soil $\mathrm{pH}$ and organic carbon, total nitrogen, total phosphorus, and total potassium (percent dry weight basis) contents were determined following standard procedures. Analysis of microbial enzymes, namely, amylase, invertase, and cellulase, was performed following the methods described in Zafar et al. [8]. Urease activity was determined by phenol-hypochlorite method [9], and phosphatase assay was based on pNPP [10].

\subsection{Microbial Analysis (Enumeration, Isolation, and Charac-} terization). For enumeration of cultivable microbial communities, isolations were carried out on a range of prescribed media following serial dilution technique. These media included tryptone yeast extract agar (TYA) and Pseudomonas isolation agar (for bacteria), actinomycetes isolation agar (for actinomycetes), and potato dextrose agar (for fungi) (all from Himedia, Bombay, India). The plates were incubated in 3 sets at $24^{\circ}, 14^{\circ}$, and $4^{\circ} \mathrm{C}$, and observations were recorded up to 3 weeks. Based on colony morphology, bacteria, actinomycetes, and fungi were carefully picked up from the agar plates; following subculture, the purified isolates were transferred onto slants and glycerol stocks for further use. Morphologically distinct isolates, each given a code number, were subjected to further investigations.

Characterization of bacterial isolates and actinomycetes was carried out following morphological (colony morphology), microscopic (Gram staining), biochemical (utilization of carbon sources and enzyme activity), growth (temperature, $\mathrm{pH}$, and salt tolerance), and cultural (oxygen requirement) characteristics on prescribed media. In case of fungi, the microscopic observations were recorded following staining the cultures with lactophenol cotton blue and observing under microscope (Nikon-Eclipse 50i, Japan). The microbial cultures were tentatively identified up to genus or species level. All the experiments were performed in triplicates.

2.4. Plant Growth Promotion and Biocontrol Activities of Soil Microorganisms. Qualitative and quantitative estimations of all the microbial isolates for phosphate solubilization were done at $24^{\circ} \mathrm{C}$ in Pikovskaya's broth medium containing tricalcium phosphate. The solubilized phosphorus in the culture filtrate was determined by using chlorostannous reduced molybdophosphoric acid blue method [11] on the seventh day. Antagonistic activity of the microbial isolates was determined by using the methods described in Chaurasia et al. [12]. The percent inhibition by the production of diffusible and volatile compounds was determined, separately. Antagonistic activities of the microbial isolates were tested against test pathogens, namely, Fusarium oxysporum and F. solani, on potato carrot agar (PCA). The production of other plant growth regulating activities, namely, ammonia, indole acetic acid (IAA), chitinase, siderophore, and hydrogen cyanide (HCN), was determined following standard procedures as described in Malviya et al. [13].

2.5. Plant Based Bioassays Using Soil Inoculum. The soil collected from the potato fields was used as consortium of "microbial inoculum" following plant based bioassays using the test crops, wheat (Triticum aestivum) and lentil (Lens esculenta), under net house of the Institute. Seeds were grown in polyethylene bags $(20.5 \times 8.0 \mathrm{~cm}$; 50 bags for each treatment). The soil was sandy loam with $\mathrm{pH} \mathrm{H}_{2} \mathrm{O}$ 6.7 and $40 \%(\mathrm{w} / \mathrm{w})$ moisture content. The treatments under consideration were (1) control (seeds without soil inoculum) and (2) seeds inoculated with soil inoculum that was taken from potato field ( $5 \mathrm{~g} / \mathrm{bag} / \mathrm{seed})$ at the time of sowing. At harvest (45 days of growth), 10 plants from each treatment were selected randomly, and fresh weight of roots and shoots was taken. Dry weight was taken after drying the roots and shoots in oven at $70^{\circ} \mathrm{C}$ for $72 \mathrm{~h}$, separately, for each plant. Rhizosphere soil samples, collected from each treatment, were analyzed for colonization of microorganisms including mycorrhizae and endophytes.

2.6. Statistics. Microsoft windows 2003 professional excel program was used to calculate means and standard deviations. One-way ANOVA was performed to determine significant difference between control and inoculated plants (in plant based bioassay).

\section{Results and Discussion}

Soil under potato cultivation was determined as sandy loam that contained organic carbon (1.75\%), phosphorus $(0.04 \%)$, potassium $(1.69 \%)$, and nitrogen $(0.14 \%)$ contents. The enzymatic activity among carbohydrases was measured as amylase $13.3 \pm 1.3$, invertase $12.4 \pm 3.8$, and cellulase $15.8 \pm 1.9 \mu \mathrm{g} / \mathrm{g}$ soil/h. Phosphatase and urease activities were measured to be $11.9 \pm 1.1$ and $2.8 \pm 0.38 \mu \mathrm{g} / \mathrm{g}$ soil/h, respectively. The value, for soil enzymatic activity, are relatively in lower range as compared to the earlier reports [14]; this can be attributed 
TABLE 1: Colony forming units $\left(\mathrm{CFU} \times 10^{5} / \mathrm{g}\right.$ soil $)$ of three groups of microbes in soil under potato cultivation.

\begin{tabular}{lccccc}
\hline Medium & Temperature $\left({ }^{\circ} \mathrm{C}\right)$ & Incubation period (weeks) & Bacteria & Actinomycetes & Fungi \\
\hline \multirow{3}{*}{ TYA } & 24 & 01 & $41.00 \pm 3.60$ & $1.66 \pm 0.57$ & $1.40 \pm 0.55$ \\
& 14 & 02 & $27.33 \pm 3.05$ & $1.66 \pm 1.15$ & $1.33 \pm 0.57$ \\
& 4 & 03 & $32.66 \pm 3.05$ & $1.33 \pm 1.15$ & $1.00 \pm 1.00$ \\
\multirow{3}{*}{ PDA } & 24 & 01 & $39.66 \pm 2.51$ & $1.33 \pm 0.57$ & $1.00 \pm 1.00$ \\
& 14 & 02 & $25.33 \pm 0.57$ & $2.66 \pm 2.08$ & $1.43 \pm 1.15$ \\
& 4 & 03 & $32.33 \pm 2.51$ & $2.00 \pm 1.00$ & $1.33 \pm 0.50$ \\
AIA & 24 & 01 & $37.00 \pm 2.64$ & $2.66 \pm 0.57$ & $1.36 \pm 0.58$ \\
& 14 & 02 & $27.66 \pm 2.51$ & $3.00 \pm 1.00$ & $1.42 \pm 0.50$ \\
& 4 & 03 & $32.33 \pm 2.88$ & $2.33 \pm 1.52$ \\
\hline
\end{tabular}

to the low activity of soil microbes under extremely low temperature environment.

The microbial colonies on agar plates were observed till $10^{-7}$ dilution, while $10^{-5}$ was found to be appropriate for enumeration of colonies. Among three sets of the plates that were incubated at 24,14 , and $4^{\circ} \mathrm{C}$, well developed colonies were obtained after one, two, and three weeks of incubation, respectively (Table 1). A total of 25 morphologically distinct isolates, bacteria (14), actinomycetes (3), and fungi (8 (including lyeast)) were obtained as pure cultures on prescribed media. Amongst bacteria, 11 whitish to cream colonies with smooth and slimy consistency were obtained from TYA plates. These were observed as Gram positive and rod shaped in varied cell arrangement (single, diplobacilli, short to long chains, or clusters in palisade arrangement). Colonies with production of mucoid substances and yellowish to greenish pigment obtained on TYA and Pseudomonas isolation agar plates were observed as Gram - ve oval rods arranged as single cells. Based on colony morphology, microscopy, and biochemical tests including utilization of carbon sources (data not presented), the Gram +ve and Gram -ve bacteria are referred as species of Bacillus and Pseudomonas, respectively. The hard pustules-like colonies with white to gray aerial mycelium developed on TYA, PDA, and AIA plates, along with branched filaments under microscope, were considered under broad category of actinomycetes. These are tentatively referred as species of Streptomyces based on morphology and comparative assessment with the available stock cultures in the laboratory. Based on colony morphology and microscopic features, the eight distinct colonies obtained from PDA were assigned to Penicillium (6), Trichocladium, and yeast (1) (Table 2). The microbial cultures exhibited wide range of tolerance for temperature, $\mathrm{pH}$, and salt concentration (Table 3).

The results on enumeration of microbes indicated the extensive colonization of soil by the major groups of microorganisms, namely, bacteria, actinomycetes, fungi, and yeast. However, these microbial communities were represented by limited number of morphotypes that can be attributed to the selection pressure caused by the stress under extremely low temperature, remaining subzero for almost six months. Potato cultivation under these conditions is also an indicative of the resilience possessed by the crop. Colonization of extreme temperature (low or high) environments by a variety of microorganisms in Himalayan region has been reported in previous studies [15-17]. Dominance of species of Bacillus in extreme conditions is attributed to the ability to resist the environmental stresses due to their spore forming nature [18]. Similarly, other bacteria, fungi mainly species of Penicillium, actinomycetes, and yeasts have been reported from extreme environments including high altitudes of Himalaya [2, 13, 1921].

All the microbial isolates exhibited activities related to plant growth promotion and biocontrol as well. Out of 25 isolates, 23 produced IAA, while 15 possessed the ability to solubilize phosphates $(1.13 \pm 0.02$ to $10.46 \pm 0.25 \mu \mathrm{g} / \mathrm{mL})$. Among biocontrol activities, 24 isolates produced ammonia, and 17 produced chitinase. In plate assays, 18 isolates inhibited the growth of test pathogens, Fusarium oxysporum, and F. solani, due to the production of diffusible and volatile antifungal compounds. Morphological abnormalities, as a result of antagonistic microbial activities, were observed under microscope in both the test fungi. None of the isolates produced HCN and siderophore (Table 4, Figure 1(a)).

The beneficial soil microbes influence plant growth through direct or indirect mechanisms. The examples of direct mechanism(s) are growth promotion by providing fixed nitrogen to the host plant, production of phytohormones, and phosphate solubilization. The indirect mechanisms mainly involve biological control of plant pathogens that may be assisted through antibiosis and production of antimicrobial substances, including siderophores, lytic enzymes, and biocidal volatiles [22-26]. Several microorganisms isolated from colder regions in IHR have been characterized for their beneficial plant growth related activities. Species of Bacillus, B. subtilis and B. megaterium in particular, have been investigated for their growth promotion abilities in agricultural [27-29] as well as forest species [30]. Similarly, cold tolerant species of Pseudomonas have been characterized for their growth promotion with particular reference to phosphate solubilization [31-33] and biocontrol abilities [34]. Selected species have also been developed in bioformulations, suitable for field application [35, 36]. The microbial isolates, obtained in the present study, were also found to be positive for the production of a range of hydrolytic enzymes. 24 isolates were positive for lipase, 19 each for protease and xylanase, 14 for amylase, 11 for pectinase, and 9 for cellulase (Figure 1(b)). Production of extracellular cell wall degrading 
TABLE 2: Colony morphology and microscopic characters of the microbial isolates.

\begin{tabular}{|c|c|c|c|}
\hline S. no. & Isolate code & Morphological and microscopic characters & Identification \\
\hline \multicolumn{4}{|c|}{ Bacteria } \\
\hline 1 & Cdpb1 & $\begin{array}{l}\text { Off white, entire, and slimy colony with } 5 \mathrm{~mm} \text { dia; Gram +ve elongated bacilli } \\
\text { in palisade or cluster arrangement; facultative anaerobic }\end{array}$ & Bacillus sp. \\
\hline 2 & Cdpb2 & $\begin{array}{l}\text { Off white, convex, slimy, and round colony with } 10 \mathrm{~mm} \text { dia; Gram +ve bacilli, } \\
\text { arranged in long chains and clusters; facultative anaerobic }\end{array}$ & Bacillus megaterium \\
\hline 3 & Cdpb4 & $\begin{array}{l}\text { Off white, entire, smooth, and round colony with } 4 \mathrm{~mm} \text { dia; Gram +ve } \\
\text { diplobacilli, arranged in clusters or short chains; facultative anaerobic }\end{array}$ & Bacillus sp. \\
\hline 4 & Cdpb5 & $\begin{array}{l}\text { Off white, entire, and slimy colony with } 6 \mathrm{~mm} \text { dia; Gram +ve bacilli arranged } \\
\text { in short chains; facultative anaerobic }\end{array}$ & Bacillus sp. \\
\hline 5 & Cdpb7 & $\begin{array}{l}\text { Off white, entire, and smooth colony with } 2-3 \mathrm{~mm} \text { dia; Gram +ve elongated } \\
\text { bacilli, arranged in clusters or short chains; facultative anaerobic }\end{array}$ & Bacillus sp. \\
\hline 6 & Cdpb8 & $\begin{array}{l}\text { Off white, convex, smooth, and round colony with } 1-2 \mathrm{~mm} \text { dia; Gram +ve } \\
\text { bacilli, arranged in palisade or short chains; facultative anaerobic }\end{array}$ & Bacillus sp. \\
\hline 7 & Cdpb10 & $\begin{array}{l}\text { Yellow, entire, and smooth colony with } 2 \mathrm{~mm} \text { dia; Gram +ve elongated bacilli, } \\
\text { arranged as single or in clusters; facultative anaerobic }\end{array}$ & Bacillus sp. \\
\hline 8 & Cdpb13 & $\begin{array}{l}\text { Off white, convex, slimy, and round colony with } 10 \mathrm{~mm} \text { dia; Gram +ve bacilli, } \\
\text { arranged as single and long chains; facultative anaerobic }\end{array}$ & Bacillus megaterium \\
\hline 9 & Cdpb16 & $\begin{array}{l}\text { White, entire, slimy, and round colony with } 3-4 \mathrm{~mm} \text { dia; Gram +ve bacilli, } \\
\text { arranged in clusters and long chains; facultative anaerobic }\end{array}$ & Bacillus megaterium \\
\hline 10 & Cdpb19 & $\begin{array}{l}\text { Light yellow, entire, smooth, and round colony with } 5 \mathrm{~mm} \text { dia; Gram -ve } \\
\text { arranged in oval or slightly curved rods; facultative anaerobic }\end{array}$ & Pseudomonas sp. \\
\hline 11 & Cdpb20 & $\begin{array}{l}\text { Light yellow, irregular rhizoid, and translucent colony with } 4-5 \mathrm{~mm} \text { dia; Gram } \\
\text { +ve diplobacilli, clusters or short chains; facultative anaerobic }\end{array}$ & Bacillus sp. \\
\hline 12 & Cdpb22 & $\begin{array}{l}\text { Greenish yellow, entire, smooth, and round colony with 6-7 mm dia; Gram } \\
\text {-ve, oval or slightly curved rods; facultative anaerobic }\end{array}$ & Pseudomonas sp. \\
\hline 13 & Cdpb23 & $\begin{array}{l}\text { Light yellow mucoid colony with } 6 \mathrm{~mm} \text { dia; Gram -ve, small curved rods; } \\
\text { facultative anaerobic }\end{array}$ & Pseudomonas sp. \\
\hline 14 & Cdpb27 & $\begin{array}{l}\text { Off white, entire, and slimy colony with } 4 \mathrm{~mm} \text { dia; Gram +ve elongated bacilli, } \\
\text { in palisade or cluster arrangement; facultative anaerobic }\end{array}$ & Bacillus sp. \\
\hline \multicolumn{4}{|c|}{ Actinomycetes } \\
\hline 15 & Cdpact28 & $\begin{array}{l}\text { Aerial mycelium gray, powdery circular colony with } 6 \mathrm{~mm} \text { dia; filaments } \\
\text { branched }\end{array}$ & Streptomyces sp. \\
\hline 16 & Cdpact29 & $\begin{array}{l}\text { Aerial mycelium white, rough, and circular colony with } 6 \mathrm{~mm} \text { dia; filaments } \\
\text { branched }\end{array}$ & Streptomyces sp. \\
\hline 17 & Cdpact30 & $\begin{array}{l}\text { Aerial mycelium gray, smooth, and circular colony with } 6 \mathrm{~mm} \text { dia; filaments } \\
\text { branched }\end{array}$ & Streptomyces sp. \\
\hline \multicolumn{4}{|c|}{ Fungi } \\
\hline 18 & Cdpf2 & Pink colony with $15 \mathrm{~mm}$ dia; mycelia septate with conidiophores & $\begin{array}{c}\text { Penicillium } \\
\text { purpurogenum } \\
\text { (NFCCI2772) }\end{array}$ \\
\hline 19 & Cdpf4 & Greenish colony with $17 \mathrm{~mm}$ dia; mycelia septate with conidiophores & $\begin{array}{l}\text { Penicillium sp. } \\
\text { (NFCCI2774) }\end{array}$ \\
\hline 20 & Cdpf5 & White colony with $10 \mathrm{~mm}$ dia; myelia septate with conidiophores & $\begin{array}{l}\text { Penicillium sp. } \\
\text { (NFCCI2775) }\end{array}$ \\
\hline 21 & Cdpf6 & White colony with $20 \mathrm{~mm}$ dia; myelia septate with conidiophores & $\begin{array}{l}\text { Penicillium sp. } \\
\text { (NFCCI2776) }\end{array}$ \\
\hline 22 & Cdpf7 & Yellow colony with $15 \mathrm{~mm}$ di; mycelia septate with branched conidiophores & Penicillium sp. \\
\hline 23 & Cdpf8 & $\begin{array}{l}\text { Off white colony with } 20 \mathrm{~mm} \text { dia; mycelia septate with branched } \\
\text { conidiophores }\end{array}$ & Penicillium sp. \\
\hline 24 & Cdpf10 & Yellowish green colony with $17 \mathrm{~mm}$ dia; septate mycelia & $\begin{array}{l}\text { Trichocladium asperum } \\
\quad \text { (NFCCI2777) }\end{array}$ \\
\hline 25 & Cdpb26 & $\begin{array}{l}\text { White, entire, smooth, and round colony with 1-2 mm dia; unicellular with } \\
\text { budding }\end{array}$ & Yeast \\
\hline
\end{tabular}

Dia: diameter; NFCCI: National Fungal Culture Collection of India, Agharkar Research Institute, Pune, India. 
TABLE 3: Physiological (temperature, $\mathrm{pH}$, and salt tolerance) characters of the microbial isolates.

\begin{tabular}{|c|c|c|c|c|}
\hline S. no. & Isolate code & Temperature $\left({ }^{\circ} \mathrm{C}\right)$ & $\mathrm{pH}$ & Salt (\%) \\
\hline \multicolumn{5}{|c|}{ Bacteria } \\
\hline 1 & Cdpb1 & 9-55 (opt. 25) & 5-11 (opt. 7) & 9 \\
\hline 2 & Cdpb2 & $4-55$ (opt. 25) & 5-11 (opt. 7) & 5 \\
\hline 3 & Cdpb4 & 4-45 (opt. 25) & 5-11 (opt. 7) & 7 \\
\hline 4 & Cdpb5 & 9-55 (opt. 25) & 5-11 (opt. 7) & 9 \\
\hline 5 & Cdpb7 & 9-45 (opt. 25) & 5-11 (opt. 7) & 9 \\
\hline 6 & Cdpb8 & $4-45$ (opt. 25) & 5-11 (opt. 7) & 9 \\
\hline 7 & Cdpb10 & $4-45$ (opt. 25) & 5-11 (opt. 7) & 7 \\
\hline 8 & Cdpb13 & $4-55$ (opt. 25) & 5-11 (opt. 7) & 5 \\
\hline 9 & Cdpb16 & $4-55$ (opt. 25) & 5-11 (opt. 7) & 5 \\
\hline 10 & Cdpb19 & 9-45 (opt. 25) & 5-11 (opt. 7) & 9 \\
\hline 11 & Cdpb20 & $4-55$ (opt. 25) & 5-11 (opt. 7) & 9 \\
\hline 12 & Cdpb22 & 9-55 (opt. 25) & 5-11 (opt. 7) & 5 \\
\hline 13 & Cdpb23 & 9-45 (opt. 25) & 5-11 (opt. 7) & 9 \\
\hline 14 & Cdpb27 & 9-45 (opt. 25) & 5-11 (opt. 7) & 9 \\
\hline \multicolumn{5}{|c|}{ Actinomycetes } \\
\hline 15 & Cdpact28 & 9-45 (opt. 25) & 5-11 (opt. 7) & 9 \\
\hline 16 & Cdpact29 & $9-45$ (opt. 25) & 5-11 (opt. 7) & 9 \\
\hline 17 & Cdpact30 & 9-45 (opt. 25) & 5-11 (opt. 7) & 7 \\
\hline \multicolumn{5}{|c|}{ Fungi } \\
\hline 18 & Cdpf2 & 9-55 (opt. 25) & 1.5-14 (opt. 6-7) & 7 \\
\hline 19 & Cdpf4 & 9-45 (opt. 25) & 1.5-14 (opt. 6-7) & 7 \\
\hline 20 & Cdpf5 & 9-55 (opt. 25) & 1.5-14 (opt. 6-7) & 7 \\
\hline 21 & Cdpf6 & 9-55 (opt. 25) & 1.5-14 (opt. 6-7) & 7 \\
\hline 22 & Cdpf7 & 9-45 (opt. 25) & 2-14 (opt. 6-7) & 7 \\
\hline 23 & Cdpf8 & 9-55 (opt. 25) & 2-14 (opt. 6-7) & 7 \\
\hline 24 & Cdpf10 & 9-45 (opt. 25) & $1.5-14$ (opt. 6-7) & 7 \\
\hline 25 & Cdpf26 & 4-55 (opt. 25) & 5-11 (opt. 6-7) & 7 \\
\hline
\end{tabular}

opt.: optimum.

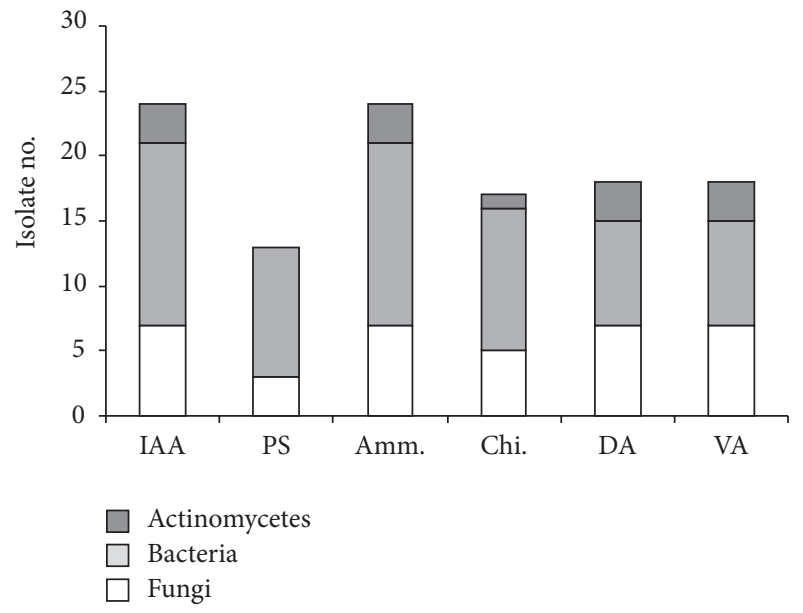

(a)

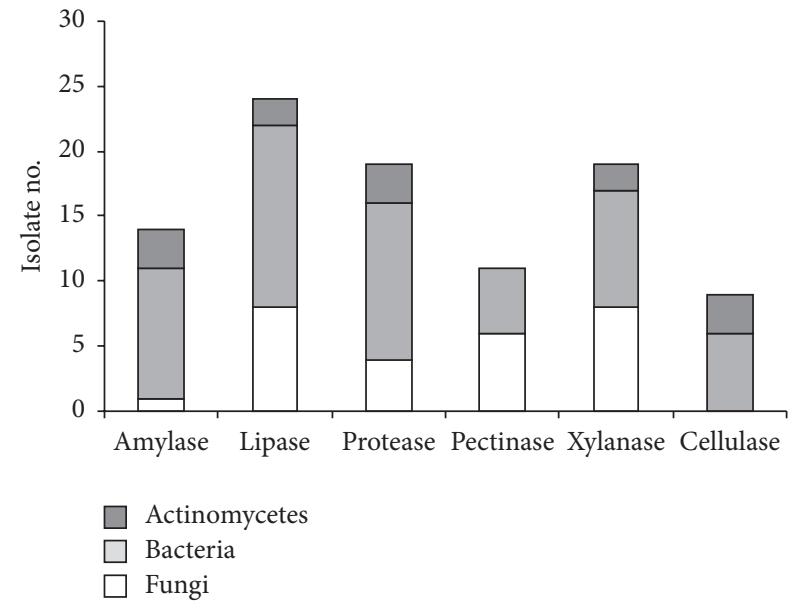

(b)

FIGURE 1: (a) Plant growth promotion and biocontrol related characters (IAA: indole acetic acid, PS: phosphate solubilization, Amm.: ammonia, Chi.: chitinase, DA: diffusible antimicrobials, VA: volatile antimicrobials). (b) Enzyme activity of the microbial isolates. 
TABLE 4: Plant growth promotion and enzymatic activities of the microbial isolates.

\begin{tabular}{|c|c|c|c|}
\hline \multirow{4}{*}{$\begin{array}{l}\text { S. no. } \\
1 \\
1\end{array}$} & \multirow{4}{*}{$\begin{array}{c}\text { Isolate code } \\
\text { Cdpb1 }\end{array}$} & \multicolumn{2}{|r|}{ Properties } \\
\hline & & \multicolumn{2}{|r|}{ Bacteria } \\
\hline & & PGP & +ve for production of IAA, chitinase, ammonia, and antimicrobials; +ve for phosphate solubilization \\
\hline & & Enzymes & +ve for amylase, lipase, protease, pectinase, cellulase, and xylanase \\
\hline \multirow[t]{2}{*}{2} & \multirow[t]{2}{*}{ Cdpb2 } & PGP & $\begin{array}{l}\text { +ve for production of IAA, chitinase, and ammonia; +ve for phosphate solubilization; -ve for } \\
\text { production of antimicrobials }\end{array}$ \\
\hline & & Enzymes & +ve for amylase, lipase, protease, pectinase, cellulase, and xylanase \\
\hline \multirow[t]{2}{*}{3} & \multirow[t]{2}{*}{ Cdpb4 } & PGP & $\begin{array}{l}\text { +ve for production of IAA, chitinase, and ammonia; +ve for phosphate solubilization; -ve for } \\
\text { production of antimicrobials }\end{array}$ \\
\hline & & Enzymes & +ve for amylase, lipase, protease, pectinase, and xylanase; -ve for cellulose \\
\hline \multirow{2}{*}{4} & \multirow{2}{*}{ Cdpb5 } & PGP & +ve for production of IAA, chitinase, ammonia, and antimicrobials; +ve for phosphate solubilization \\
\hline & & Enzymes & +ve for amylase, lipase, protease, pectinase, and xylanase; -ve for cellulose \\
\hline \multirow[t]{2}{*}{5} & \multirow[t]{2}{*}{ Cdpb7 } & PGP & $\begin{array}{l}\text { +ve for production of IAA, ammonia, and antimicrobials; -ve for chitinase and phosphate } \\
\text { solubilization }\end{array}$ \\
\hline & & Enzymes & +ve for amylase, lipase, and protease; -ve for pectinase, cellulase, and xylanase \\
\hline \multirow[t]{2}{*}{6} & \multirow[t]{2}{*}{ Cdpb8 } & PGP & $\begin{array}{l}\text { +ve for production of IAA, ammonia, and antimicrobials; -ve for chitinase and phosphate } \\
\text { solubilization }\end{array}$ \\
\hline & & Enzymes & +ve for amylase, lipase, and protease; -ve for pectinase, cellulase, and xylanase \\
\hline \multirow[t]{2}{*}{7} & \multirow[t]{2}{*}{ Cdpb10 } & PGP & $\begin{array}{l}\text { +ve for production of IAA and ammonia; -ve for chitinase, antimicrobials, and phosphate } \\
\text { solubilization }\end{array}$ \\
\hline & & Enzymes & +ve for lipase, cellulase, and pectinase; -ve for amylase, protease, xylanase \\
\hline \multirow[t]{2}{*}{8} & \multirow[t]{2}{*}{ Cdpb13 } & PGP & $\begin{array}{l}\text { +ve for production of IAA, chitinase, and ammonia; -ve for phosphate solubilization and } \\
\text { antimicrobials }\end{array}$ \\
\hline & & Enzymes & +ve for amylase, lipase, and xylanase; -ve for protease, pectinase and cellulose \\
\hline \multirow[t]{2}{*}{9} & \multirow{2}{*}{ Cdpb16 } & PGP & +ve for production of IAA, chitinase, antimicrobials, and ammonia; +ve for phosphate solubilization \\
\hline & & Enzymes & +ve for amylase, lipase, protease, and xylanase; -ve for pectinase and cellulose \\
\hline \multirow[t]{2}{*}{10} & \multirow[t]{2}{*}{ Cdpb19 } & PGP & $\begin{array}{l}\text { +ve for production of IAA, chitinase, and ammonia; +ve for phosphate solubilization; -ve for } \\
\text { antimicrobials }\end{array}$ \\
\hline & & Enzymes & +ve for lipase, protease, and cellulase; -ve for amylase, pectinase, and xylanase \\
\hline \multirow{2}{*}{11} & \multirow{2}{*}{ Cdpb20 } & PGP & +ve for production of IAA, chitinase, ammonia, and antimicrobials; +ve for phosphate solubilization \\
\hline & & Enzymes & +ve for lipase, protease, and cellulase, -ve for amylase, pectinase, and xylanase \\
\hline \multirow[t]{2}{*}{12} & \multirow[t]{2}{*}{ Cdpb22 } & PGP & $\begin{array}{l}\text { +ve for production of IAA, chitinase, and ammonia; +ve for phosphate solubilization; -ve for } \\
\text { antimicrobials }\end{array}$ \\
\hline & & Enzymes & +ve for amylase, lipase, and protease, xylanase; -ve for pectinase and cellulose \\
\hline \multirow{2}{*}{13} & \multirow{2}{*}{ Cdpb23 } & PGP & +ve for production of IAA, chitinase, ammonia, and antimicrobials; +ve for phosphate solubilization \\
\hline & & Enzymes & +ve for lipase, protease, and xylanase; -ve for amylase, cellulose, and pectinase \\
\hline \multirow{2}{*}{14} & Cdpb27 & PGP & +ve for production of IAA, chitinase, ammonia, and antimicrobials; +ve for phosphate solubilization \\
\hline & & Enzymes & +ve for amylase, lipase, protease, cellulase, and xylanase; -ve for pectinase \\
\hline & & & Actinomycetes \\
\hline 15 & Cdpact28 & PGP & $\begin{array}{l}\text { +ve for production of IAA, ammonia, and antimicrobials; -ve for chitinase and phosphate } \\
\text { solubilization }\end{array}$ \\
\hline & & Enzymes & +ve for amylase, protease, and cellulase, -ve for lipase, xylanase, and pectinase \\
\hline 16 & Cdpact29 & PGP & +ve production of IAA, chitinase, ammonia, and antimicrobials; -ve for phosphate solubilization \\
\hline & & Enzymes & +ve for amylase, lipase, protease, cellulase, and xylanase; -ve for pectinase \\
\hline 17 & Cdpact30 & PGP & $\begin{array}{l}\text { +ve for production of IAA, ammonia, and antimicrobials; -ve for chitinase and phosphate } \\
\text { solubilization }\end{array}$ \\
\hline & & Enzymes & +ve for amylase, lipase, protease, and cellulase, xylanase; -ve for pectinase \\
\hline
\end{tabular}


TABLE 4: Continued.

\begin{tabular}{|c|c|c|c|}
\hline \multirow{4}{*}{$\begin{array}{l}\text { S. no. } \\
18\end{array}$} & \multirow{4}{*}{$\begin{array}{c}\text { Isolate code } \\
\text { Cdpf2 }\end{array}$} & \multicolumn{2}{|r|}{ Properties } \\
\hline & & \multicolumn{2}{|r|}{ Fungi } \\
\hline & & PGP & +ve for production of IAA, chitinase, ammonia, and antimicrobials; +ve for phosphate solubilization \\
\hline & & Enzymes & +ve for amylase, lipase, protease, xylanase, and pectinase; -ve for cellulose \\
\hline \multirow[t]{2}{*}{19} & \multirow[t]{2}{*}{ Cdpf4 } & PGP & $\begin{array}{l}\text { +ve for production of IAA, ammonia, and antimicrobials; - ve for chitinase and phosphate } \\
\text { solubilization }\end{array}$ \\
\hline & & Enzymes & +ve for lipase, xylanase, and pectinase; -ve for amylase, protease, and cellulose \\
\hline \multirow{2}{*}{20} & \multirow{2}{*}{ Cdpf5 } & PGP & +ve for production of IAA, chitinase, ammonia, and antimicrobials; -ve for phosphate solubilization \\
\hline & & Enzymes & +ve for lipase, xylanase, and pectinase; -ve for amylase, protease, and cellulase \\
\hline \multirow[t]{2}{*}{21} & \multirow[t]{2}{*}{ Cdpf6 } & PGP & $\begin{array}{l}\text { +ve for production of IAA, ammonia and antimicrobials; -ve for chitinase and phosphate } \\
\text { solubilization }\end{array}$ \\
\hline & & Enzymes & +ve for lipase, xylanase, pectinase; -ve for amylase, protease, and cellulose \\
\hline \multirow[t]{2}{*}{22} & \multirow[t]{2}{*}{ Cdpf7 } & PGP & $\begin{array}{l}\text { +ve for production of chitinase, antimicrobials, and phosphate solubilization; -ve for IAA and } \\
\text { ammonia }\end{array}$ \\
\hline & & Enzymes & +ve for lipase, protease, and xylanase, -ve for amylase, cellulose, and pectinase \\
\hline \multirow[t]{2}{*}{23} & \multirow[t]{2}{*}{ Cdpf8 } & PGP & $\begin{array}{l}\text { +ve for production of ammonia and antimicrobials; -ve for IAA, chitinase, and phosphate } \\
\text { solubilization }\end{array}$ \\
\hline & & Enzymes & +ve for lipase, protease, xylanase, and pectinase, -ve for amylase, cellulose \\
\hline \multirow{2}{*}{24} & \multirow{2}{*}{ Cdpf10 } & PGP & +ve for production of IAA, chitinase, ammonia, and antimicrobials; -ve for phosphate solubilization \\
\hline & & Enzymes & +ve lipase, xylanase, and pectinase; -ve for amylase, protease, and cellulose \\
\hline \multirow{2}{*}{25} & \multirow{2}{*}{ Cdpf26 } & PGP & +ve for production of IAA, chitinase, ammonia and phosphate solubilization; -ve for antimicrobials \\
\hline & & Enzymes & +ve for lipase, protease, and xylanase; -ve for amylase, cellulose, and pectinase \\
\hline
\end{tabular}

PGP: plant growth promotion.

TABLE 5: Effect of inoculation on growth of test crops in net house conditions.

\begin{tabular}{lcccc}
\hline Treatment & Shoot length $(\mathrm{cm})$ & Shoot weight $(\mathrm{g})$ & Root length $(\mathrm{cm})$ & Root weight $(\mathrm{g})$ \\
\hline & & Wheat & & \\
Control & $47.17 \pm 8.71$ & $0.68 \pm 0.22$ & $16.75 \pm 3.17$ & $0.20 \pm 0.05$ \\
Inoculated & $62.11 \pm 12.31^{*}$ & $1.30 \pm 0.80^{*}$ & $21.11 \pm 3.87^{*}$ & $0.63 \pm 0.39^{*}$ \\
\hline & & & \\
Control & $24.29 \pm 2.86$ & $0.71 \pm 0.20$ & $12.61 \pm 2.56$ & $0.10 \pm 0.04$ \\
Inoculated & $28.27 \pm 3.63^{*}$ & $0.78 \pm 0.30$ & $16.58 \pm 3.44^{*}$ & $0.18 \pm 0.09^{*}$ \\
\hline
\end{tabular}

Values are mean $\pm \mathrm{SD}(n=15) ;{ }^{*}$ significant at $P \leq 0.05$.

enzymes has been associated with biocontrol abilities in plant growth promoting microbes $[13,37]$.

The influence due to the presence of plant growth promoting microbes was demonstrable when the soil was used in form of inoculum representing a "consortium" of beneficial microbes. Inoculation with soil consortium showed positive effects on plant growth related parameters such as length and dry weight of the root and shoot of the test crops, that is, wheat and lentil $(P \leq 0.05)$ (Table 5$)$. The inoculation also resulted in stimulation of rhizosphere microorganisms $(P \leq$ $0.05)$, mainly bacteria and actinomycetes. The roots were also observed with moderate colonization by mycorrhizae (up to $30 \%$ ) along with colonization of endophytes, mainly bacterial and fungal (up to $80 \%$ ). Use of small proportion of rhizosphere soil in appropriate ratio has been reported for raising healthy seedlings of forest species of Himalayan region [38].

\section{Conclusion}

The distinct feature of the present study is the geographic location used for potato cultivation where soil remains snow clad for almost six months, before and after crop season. It presented a unique ecological niche, where the crop along with a consortium of beneficial microbes evolves and adapts to the prevailing edaphic and climatic conditions. The analyses of soil for microbial communities indicated toward the importance of selection pressure in the survival and dominance of selected group of microbes under stress conditions. The environment under snow cover is likely to act as a limiting factor for survival of the soil microflora. The best of the survivors then multiply and tend to rapidly increase in number and dominate. As a consequence, although maintaining the low nutrition status in terms of nutrients and enzymes, the soil under potato cultivation was 
able to colonize higher counts that were enumerated up to $10^{-7}$ dilution. The dominance of microbes, linked with plant growth promotion and biocontrol activities, allowed the transformation of soil in form of a natural consortium. This consortium consisted of native beneficial microbes mainly belonging to the species of Bacillus, Pseudomonas, and Penicillium, along with actinomycetes and yeast. Potato, being valuable food crop worldwide, has received attention in view of the colonization of plant growth promoting microbes in potato fields $[39,40]$. Plant growth promoting microbes are also receiving attention for their associated importance in bioremediation $[41,42]$.

\section{Conflict of Interests}

The authors declare that they have no conflict of interests.

\section{Acknowledgments}

Director of GBPIHED is acknowledged for extending the facilities. Ministry of Environment and Forests, Government of India, New Delhi, is acknowledged for financial support.

\section{References}

[1] A. Pandey and L. M. S. Palni, "The rhizosphere effect in trees of the Indian Central Himalaya with special reference to altitude," Applied Ecology and Environmental Research, vol. 5, no. 1, pp. 93-102, 2007.

[2] R. Margesin, "Effect of temperature on growth parameters of psychrophilic bacteria and yeasts," Extremophiles, vol. 13, no. 2, pp. 257-262, 2009.

[3] P. K. Mishra, S. C. Bisht, J. K. Bisht, and J. C. Bhatt, "Coldtolerant PGPRs as bioinoculants for stress management," in Bacteria in Agrobiology: Stress Management, D. K. Maheshwari, Ed., pp. 95-118, Springer, Berlin, Germany, 2012.

[4] A. Pandey, A. Durgapal, M. Joshi, and L. M. S. Palni, "Influence of Pseudomonas corrugata inoculation on root colonization and growth promotion of two important hill crops," Microbiological Research, vol. 154, no. 3, pp. 259-266, 1999.

[5] P. Trivedi, B. Kumar, A. Pandey, and L. M. S. Palni, "Growth promotion of rice by phosphate solubilizing bioinoculants in a Himalayan location," in Plant and Soil, Developments in Plant and Soil Sciences, First International Meeting on Microbial Phosphate Solubilization, E. Velazqez and C. Rodriguez-Barrueco, Eds., vol. 102, pp. 291-299, Springer, 2007.

[6] P. Trivedi, A. Pandey, and L. M. S. Palni, "Bacterial inoculants for field applications under Mountain Ecosystem: present initiatives and future prospects," in Bacteria in Agrobiology, Plant Probiotics, D. K. Maheshwari, Ed., pp. 15-44, Springer, 2012.

[7] V. Kumar, P. Singh, M. A. Jorquera et al., "Isolation of phytaseproducing bacteria from Himalayan soils and their effect on growth and phosphorus uptake of Indian mustard (Brassica juncea)," World Journal of Microbiology and Biotechnology, vol. 29, no. 8, pp. 1361-1369, 2013.

[8] Y. Zafar, K. A. Malik, and A. H. Chaudhary, "Activities of some carbohydrases in agricultural soils," Pakistan Journal of Agricultural Research, vol. 2, no. 1, pp. 41-45, 1981.
[9] J. K. Fawcett and J. E. Scott, "A rapid and precise method for the determination of urea," Journal of clinical pathology, vol. 13, pp. 156-159, 1960.

[10] M. A. Tabatabai and J. M. Bremner, "Use of p-nitrophenyl phosphate for assay of soil phosphatase activity," Soil Biology and Biochemistry, vol. 1, no. 4, pp. 301-307, 1969.

[11] M. L. Jackson, Soil Chemical Analysis, Prentice-Hall, New Delhi, India, 1967.

[12] B. Chaurasia, A. Pandey, L. M. S. Palni, P. Trivedi, B. Kumar, and N. Colvin, "Diffusible and volatile compounds produced by an antagonistic Bacillus subtilis strain cause structural deformations in pathogenic fungi in vitro," Microbiological Research, vol. 160, no. 1, pp. 75-81, 2005.

[13] M. K. Malviya, A. Pandey, P. Trivedi, G. Gupta, and B. Kumar, "Chitinolytic activity of cold tolerant antagonistic species of streptomyces isolated from glacial sites of Indian Himalaya," Current Microbiology, vol. 59, no. 5, pp. 502-508, 2009.

[14] C. Trasar-Cepeda, M. C. Leirós, and F. Gil-Sotres, "Hydrolytic enzyme activities in agricultural and forest soils. Some implications for their use as indicators of soil quality," Soil Biology and Biochemistry, vol. 40, no. 9, pp. 2146-2155, 2008.

[15] A. Ghildiyal and A. Pandey, "Isolation of cold tolerant antifungal strains of Trichoderma sp. from glacial sites of Indian Himalayan Region," Research Journal of Microbiology, vol. 3, no. 8, pp. 559-564, 2008.

[16] K. Rinu and A. Pandey, "Temperature-dependent phosphate solubilization by cold- and $\mathrm{pH}$-tolerant species of Aspergillus isolated from Himalayan soil," Mycoscience, vol. 51, no. 4, pp. 263-271, 2010.

[17] A. Sharma, A. Pandey, Y. S. Shouche, B. Kumar, and G. Kulkarni, "Characterization and identification of Geobacillus spp. isolated from Soldhar hot spring site of Garhwal Himalaya, India," Journal of Basic Microbiology, vol. 49, no. 2, pp. 187-194, 2009.

[18] W. Mongkolthanaruk, "Classification of bacillus beneficial substances related to plants, humans and animals," Journal of Microbiology and Biotechnology, vol. 22, no. 12, pp. 1597-1604, 2012.

[19] A. Pandey, L. M. S. Palni, and D. Bisht, "Dominant fungi in the rhizosphere of established tea bushes and their interaction with the dominant bacteria under in situ conditions," Microbiological Research, vol. 156, no. 4, pp. 377-382, 2001.

[20] A. Pandey, N. Das, B. Kumar, K. Rinu, and P. Trivedi, "Phosphate solubilization by Penicillium spp. isolated from soil samples of Indian Himalayan region," World Journal of Microbiology and Biotechnology, vol. 24, no. 1, pp. 97-102, 2008.

[21] S. A. Cantrell, J. C. Dianese, J. Fell, N. Gunde-Cimerman, and P. Zalar, "Unusual fungal niches," Mycologia, vol. 103, no. 6, pp. 1161-1174, 2011.

[22] B. Lugtenberg and F. Kamilova, "Plant-growth-promoting rhizobacteria," Annual Review of Microbiology, vol. 63, pp. 363-383, 2009.

[23] P. N. Bhattacharyya and D. K. Jha, "Plant growth-promoting rhizobacteria (PGPR): emergence in agriculture," World Journal of Microbiology and Biotechnology, vol. 28, no. 4, pp. 1327-1350, 2012.

[24] N. Vassilev, B. Eichler-Löbermann, and M. Vassileva, "Stresstolerant P-solubilizing microorganisms," Applied Microbiology and Biotechnology, vol. 95, pp. 851-859, 2012.

[25] B. R. Glick, "Plant growth-promoting bacteria: mechanisms and applications," vol. 2012, Article ID 963401, 15 pages, 2012. 
[26] A. Pandey, L. M. S. Palni, and N. Coulomb, "Antifungal activity of bacteria isolated from the rhizosphere of established tea bushes," Microbiological Research, vol. 152, no. 1, pp. 105-112, 1997.

[27] K. Rinu and A. Pandey, "Bacillus subtilis NRRL B-30408 inoculation enhances the symbiotic efficiency of Lens esculenta Moench at a Himalayan location," Journal of Plant Nutrition and Soil Science, vol. 172, no. 1, pp. 134-139, 2009.

[28] M. K. Malviya, A. Sharma, A. Pandey, K. Rinu, P. Sati, and L. M. S. Palni, "Bacillus subtilis NRRL B-30408: a potential inoculant for crops grown under rainfed conditions in the mountains," Journal of Soil Science and Plant Nutrition, vol. 12, pp. 811-824, 2012.

[29] P. Trivedi and A. Pandey, "Plant growth promotion abilities and formulation of Bacillus megaterium strain B 388 (MTCC6521) isolated from a temperate Himalayan location," Indian Journal of Microbiology, vol. 48, no. 3, pp. 342-347, 2008.

[30] D. Bisht, A. Pandey, and L. M. S. Palni, "Influence of microbial inoculations on Cedrus deodara in relation to survival, growth promotion and nutrient uptake of seedling and general soil microflora," Journal of Sustainable Forestry, vol. 17, no. 3, pp. 3754, 2003.

[31] A. Pandey, L. M. S. Palni, P. Mulkalwar, and M. Nadeem, "Effect of temperature on solubilization of tricalcium phosphate by Pseudomonas corrugata," Journal of Scientific and Industrial Research, vol. 61, no. 6, pp. 457-460, 2002.

[32] P. K. Mishra, S. Mishra, G. Selvakumar et al., "Characterisation of a psychrotolerant plant growth promoting Pseudomonas sp. strain PGERs17 (MTCC 9000) isolated from North Western Indian Himalayas," Annals of Microbiology, vol. 58, no. 4, pp. 561-568, 2008.

[33] G. Selvakumar, P. Joshi, S. Nazim, P. K. Mishra, J. K. Bisht, and H. S. Gupta, "Phosphate solubilization and growth promotion by Pseudomonas fragi CS11RH1 (MTCC 8984), a psychrotolerant bacterium isolated from a high altitude Himalayan rhizosphere," Biologia, vol. 64, no. 2, pp. 239-245, 2009.

[34] A. Pandey, L. M. S. Palni, and K. P. Hebbar, "Suppression of damping-off in maize seedlings by Pseudomonas corrugata," Microbiological Research, vol. 156, no. 2, pp. 191-194, 2001.

[35] P. Trivedi, A. Pandey, and L. M. S. Palni, "Carrier-based preparations of plant growth-promoting bacterial inoculants suitable for use in cooler regions," World Journal of Microbiology and Biotechnology, vol. 21, no. 6-7, pp. 941-945, 2005.

[36] P. Trivedi and A. Pandey, "Recovery of plant growth-promoting rhizobacteria from sodium alginate beads after 3 years following storage at $4^{\circ} \mathrm{C}$," Journal of Industrial Microbiology and Biotechnology, vol. 35, no. 3, pp. 205-209, 2008.

[37] N. Someya, K. Tsuchiya, T. Yoshida, M. T. Noguchi, K. Akutsu, and H. Sawada, "Co-inoculation of an antibiotic-producing bacterium and a lytic enzyme-producing bacterium for the biocontrol of tomato wilt caused by Fusarium oxysporum $\mathrm{f}$. sp. lycopersici," Biocontrol Science, vol. 12, no. 1, pp. 1-6, 2007.

[38] A. Durgapal, A. Pandey, and L. M. S. Palni, "The use of rhizosphere soil for improved establishment of conifers at nursery stage for application in plantation programmes," Journal of Sustainable Forestry, vol. 15, no. 3, pp. 57-73, 2002.

[39] P. Calvo, E. Ormeño-Orrillo, E. Martínez-Romero, and D. Zúñiga, "Characterization of bacillus isolates of potato rhizosphere from Andean soils of Peru and their potential PGPR characteristics," Brazilian Journal of Microbiology, vol. 41, no. 4, pp. 899-906, 2010.
[40] J. Ghyselinck, S. L. S. Velivelli, K. Heylen et al., "Bioprospecting in potato fields in the central andean highlands: screening of rhizobacteria for plant growth-promoting properties," Systematic and Applied Microbiology, vol. 36, no. 2, pp. 116-127, 2013.

[41] X. Zhuang, J. Chen, H. Shim, and Z. Bai, "New advances in plant growth-promoting rhizobacteria for bioremediation," Environment International, vol. 33, no. 3, pp. 406-413, 2007.

[42] K. P. Shukla, S. Sharma, N. K. Singh, and V. Singh, "Deciphering rhizosphere soil system for strains having plant growth promoting and bioremediation traits," Agriculture Research, vol. 1, no. 3, pp. 251-257, 2012. 

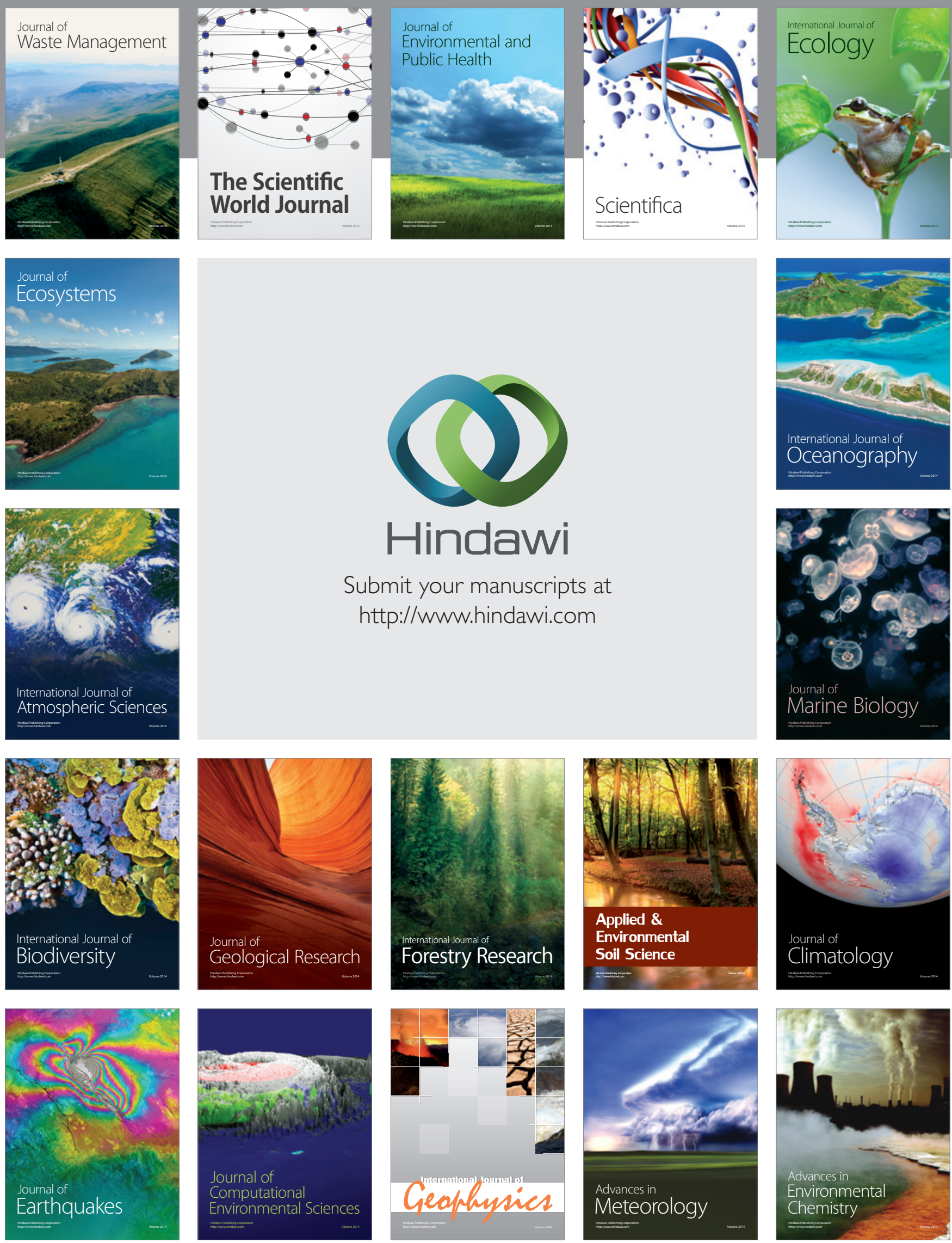